\title{
Photosynthetic activity of stems in two Clusia species
}

\author{
Maciej Kocurek $^{1}$ - Andrzej Kornas ${ }^{2} \cdot$ Jan Pilarski $^{1} \cdot$ Krzysztof Tokarz $^{3,4}$. \\ Ulrich Lüttge $^{5} \cdot$ Zbigniew Miszalski $^{3,6}$
}

Received: 24 November 2014/Revised: 15 January 2015/Accepted: 27 February 2015/Published online: 13 March 2015

(C) The Author(s) 2015. This article is published with open access at Springerlink.com

\begin{abstract}
Key message In stems of Clusia, $\mathrm{CO}_{2}$ concentrated in the xylem sap in CAM trees can be fixed by PEPC and Rubisco, while in $\mathbf{C}_{3}$ trees only Rubisco is engaged.

Abstract The photosynthetic characteristics of 7-8-yearold stems of two tropical trees representing the Clusiaceae family were compared: Clusia multiflora Kunth. described as an obligate $\mathrm{C}_{3}$ and Clusia rosea Jacq. as an obligate CAM plant. Photosynthetic gas exchange, xylem $\mathrm{CO}_{2}$ concentration, chlorophyll distribution, ${ }^{13} \mathrm{C}$ discrimination, daily malate and citrate fluctuations and the abundance of Rubisco (ribulose-1,5-bisphosphate carboxylase/oxygenase) and PEPC (phosphoenolpyruvate carboxylase) proteins were measured in leaves and stems. In stems of both species a low $\mathrm{CO}_{2}$ efflux (in the range of $0.05-0.1 \mu \mathrm{mol} \mathrm{m} \mathrm{m}^{-2} \mathrm{~s}^{-1}$ ) was observed as a result of
\end{abstract}

Communicated by H. Pfanz.

Zbigniew Miszalski

miszalski@ifr-pan.krakow.pl

1 Institute of Biology, Jan Kochanowski University, ul. Świętokrzyska 15, 25-406 Kielce, Poland

2 Institute of Biology, Pedagogical University, ul. Podchorążych 2, 30-084 Kraków, Poland

3 The Franciszek Górski Institute of Plant Physiology of the Polish Academy of Sciences, ul. Niezapominajek 21, 30-239 Kraków, Poland

4 Institute of Plant Biology and Biotechnology, Unit of Botany and Plant Physiology, al. 29 Listopada 54, 31-425 Kraków, Poland

5 Department of Biology, Technical University Darmstadt, Schnittspahnstraße 3-5, 64287 Darmstadt, Germany

6 Malopolska Center of Biotechnology, Jagiellonian University, ul. Gronostajowa 7A, 30-387 Kraków, Poland extremely low cork conductance for water vapor (0.15-0.2 $\left.\mathrm{mmol} \mathrm{m}^{-2} \mathrm{~s}^{-1}\right)$. This led to the $\mathrm{CO}_{2}$ concentration in xylem sap reaching $5.2\left(\mathrm{CO}_{2}{ }^{*}\right) \mathrm{mmol}^{-1}$. The substantial amount of chlorophyll in the outer part of the bark and light-induced decrease of $\mathrm{CO}_{2}$ concentration within the xylem can be explained by photosynthetic activity in this tissue. Moreover, Western blotting analyses proved the presence of Rubisco in the stems of both Clusia species; however, PEPC was only found in C. rosea. Additionally, daily fluctuations in the concentration of citrate and malate (higher than in leaves) and significant enrichment in ${ }^{13} \mathrm{C}$ in $C$. rosea stems were observed. These facts allow us to conclude that the examined stems of $C$. rosea and $C$. multiflora represent specific types of photosynthetic metabolism.

Keywords $\beta$-Carboxylation - Citrate $\cdot{ }^{13} \mathrm{C}$ discrimination $\cdot$ Malate $\cdot$ Corticular photosynthesis $\cdot$ Stems

\section{Introduction}

Most photosynthesizing plant species are equipped with two carboxylating enzymes, Rubisco and phosphoenolpyruvate carboxylase (PEPC). Usually in $\mathrm{C}_{3}$ plants PEPC is present in much lower amounts than Rubisco in many tissues and can fix (prefix) $\mathrm{CO}_{2}\left(\right.$ as $\left.\mathrm{HCO}_{3}{ }^{-}\right)$in the cytoplasm, which results in an increase of malate or citrate levels. These processes can be very intensive and are characteristic for some heterotrophic tissues in $\mathrm{C}_{4}$ and also CAM (crassulacean acid metabolism) plants (both described as $\beta$-carboxylating plants). In photosynthetical tissues after decarboxylation of malate or citrate, $\mathrm{CO}_{2}$ can be fixed again by Rubisco. PEPC expression is a major factor underpinning the genotypic capacity for CAM (Taybi et al. 2004). 
Most literature concerning photosynthesis describes the process of fixing atmospheric $\mathrm{CO}_{2}$ in leaf blade mesophyll tissues. We know that within leaf blades also cells associated with veins are performing photosynthesis and also cells within stems contain significant amounts of chlorophyll. In addition, the carbon present as malate in the transpiration stream may be used for photosynthesis. This was shown in Arabidopsis leaves, a $\mathrm{C}_{3}$ model plant species (Janacek et al. 2009). As was reported by Hibberd and Quick (2002) in experiments on the $\mathrm{C}_{3}$ plant Nicotiana sp., leaf veins are able to perform $\mathrm{C}_{4}$-similar photosynthesis using carbon fixed by PEPC in their roots. Malate (after pre-fixation of $\mathrm{CO}_{2}$ ) is transported within the vascular bundles to leaf mesophyll tissues. It seems that photosynthesis taking part within stems and leaf veins plays a significant role in many physiological processes. It was also possible to determine that photosynthesis in cells close to veins was quantitatively important for growth fitness (Janacek et al. 2009). According to other authors, most $\mathrm{CO}_{2}$ within the stem originates from living cells in the stems and roots. In woody plants, because of the large size of xylem, $\mathrm{CO}_{2}$ accumulation can occur. It has been found that the concentration of $\mathrm{CO}_{2}$ in the xylem sap changes daily and seasonally, and it also depends on many environmental factors including temperature, drought and light conditions (Saveyn et al. 2007; Teskey et al. 2008; Etzold et al. 2013).

According to the type of the photosynthetic mechanism performed within leaves, most trees are classified as $\mathrm{C}_{3}$ plants, but in vascular tissues of stems, especially young branches, photosynthesis occurs mostly by refixing the internal respiratory $\mathrm{CO}_{2}$ (Berveiller and Damesin 2008). However, in this research the possibility of $\mathrm{CO}_{2}$ production due to decarboxylation of malate and citrate was not taken into account.

In experiments on eight tree species (deciduous and evergreen: Ginkgo biloba, Fagus sylvatica, Tilia cordata, Betula pendula, Quercus robur, Fraxinus excelsior, Alnus glutinosa, Picea abies, Pinus sylvestris), it was also shown that the decrease in $\mathrm{CO}_{2}$ efflux from stems in the light is mainly due to increased assimilation rather than to reduced respiration (Berveiller et al. 2007). Stem maximal Rubisco and PEPC activities occurred at the beginning of the season when the chlorophyll content, chla/chl $b$ ratio and $\mathrm{CO}_{2}$ assimilation rate are also maximal. The PEPC/Rubisco activity ratio in the stems of the tested tree species was on average 3.6, while the value for leaves in $\mathrm{C}_{3}$ plants is 0.1 and for $\mathrm{C}_{4}$ plants 10.0 (Berveiller and Damesin 2008).

Different methods can be used to evaluate the role of both carboxylases in gaining atmospheric $\mathrm{CO}_{2}$, but their participation in the general metabolism is difficult to estimate. Analyzing the net photosynthesis, it is quite easy to distinguish between $\mathrm{C}_{3}$ and CAM plants (Taybi et al. 2004; Teskey et al. 2008). When measuring the activity of the enzymes involved in both metabolic pathways, we have to take seasonal and daily changes into account. Their activities can be subjected to many transcriptional and posttranscriptional regulations. Both carboxylating enzymes, PEPC and Rubisco, discriminate the ${ }^{13} \mathrm{C}$ isotope differently, and this phenomenon can help to evaluate their overall activity during growth.

The relative abundance of the stable carbon isotopes varies in nature (Nier and Gulbransen 1939). Such variation was reported to exist among plant taxa and among plants growing in different environments (Cernusak et al. 2013) as well as species using different photosynthetic metabolism, $\mathrm{C}_{3}, \mathrm{C}_{4}$ and CAM (Craig 1953; Farquhar 1983; Cernusak et al. 2008). The ${ }^{13} \mathrm{C}$ discrimination values for the new biomass of CAM plants obtained solely during the dark (PEPC) and light (PEPC and Rubisco) were estimated as -8.7 and $-26.9 \%$, respectively. Farquhar (1983) showed that fractionation associated with PEPC is $-5.7 \%$ and that associated with Rubisco $-29.0 \%$. Following this, according to Cernusak et al. (2009), non-photosynthetic or heterotrophic tissues in $\mathrm{C}_{3}$ plants tend to be enriched in ${ }^{13} \mathrm{C}$ (less significant discrimination) compared with the leaves that supply them with photosynthate. This would indicate that nonphotosynthetic tissues can fix $\mathrm{CO}_{2}$ independent of the Calvin cycle pathway, and we may explain this by ${ }^{13} \mathrm{C}$ discrimination caused by PEPC and Rubisco. We can also expect that stems can use, at least in part, other sources of carbon than that fixed by Rubisco in leaves. Craig (1953) observed that the branch wood of several tree species was enriched in ${ }^{13} \mathrm{C}$ compared with leaves. This means that the ${ }^{13} \mathrm{C}$ discrimination factor of branch wood reaching $-25.8 \%$ was significantly less negative than that of leaves at $-26.8 \%$. Badeck et al. (2005) also calculated that woody stems were on average enriched in ${ }^{13} \mathrm{C}$ by $1.9 \%$ compared with leaves. Also young emerging leaves of $\mathrm{C}_{3}$ plants, for which growth may be mostly heterotrophic, tend to be ${ }^{13} \mathrm{C}$-enriched (Damesin and Lelarge 2003), and later during the development of the photosynthetic apparatus this factor is lowered, indicating an increase in Rubisco activity.

In addition to the above-mentioned literature, it is worth noting that ${ }^{13} \mathrm{C}$-rich molecules are discriminated in many reactions. It was shown that significant discrimination of ${ }^{13} \mathrm{C}$-rich pyruvate by pyruvate dehydrogenase causes reduced ${ }^{13} \mathrm{C}$ levels in fatty acids. Therefore, thylakoid membranes have reduced ${ }^{13} \mathrm{C}$ levels. This may affect ${ }^{13} \mathrm{C}$ levels in tissues, especially those rich in chloroplasts (DeNiro and Epstein 1977).

Malate and citrate synthesized in $\beta$-carboxylation because of the PEPC action play a crucial role, and both acids 
can provide $\mathrm{CO}_{2}$ during the time when it is limited. In our previous experiments (Miszalski et al. 2013) done on Clusia hilariana CAM tree leaves, we showed that fluctuations of malate and citrate are independent, and at low light citrate can even be accumulated opposite to malate, which is decarboxylated. In $C$. alata CAM plants, decarboxylation of citrate during the daytime is delayed in comparison to decarboxylation of malate (Kornas et al. 2009).

In many stem succulent CAM plants, accumulation of carbon takes place just in stems (Lüttge 2004). Leaves of many Clusia plants show very high flexibility in $\beta$-carboxylation, but some species are obligatory $\mathrm{C}_{3}$ or CAM. We know that the main veins behave differently from the leaf blade in $C$. minor leaves exposed to photorespiratory and non-photorespiratory conditions (Lüttge 2008). Nothing is known about the activity of $\beta$-carboxylation in stems of Clusia plants that use this type of metabolism intensively and flexibly in their leaves. Are stems of the obligatory $\mathrm{C}_{3}$ plants able to perform intensive $\beta$-carboxylation similar to obligatory CAM species? Are stems of the obligatory CAM species active in using this type of $\mathrm{CO}_{2}$ gaining? Is carbon fixed within stems also transported to other tissues?

The present study aims to improve the physiological characterization of stem photosynthesis by examining the enzymatic characteristics. The two enzymes that are crucial in $\mathrm{CO}_{2}$ fixation and $\beta$-carboxylating metabolism, respectively, were investigated in stems of obligatory $\mathrm{C}_{3}$ and CAM species (C. multiflora and $C$. rosea, respectively) and were compared to the corresponding characteristics of leaves.

\section{Materials and methods}

\section{Plant material}

The experiments were carried out on 8-10-year-old C. multiflora and C. rosea trees. Plants were grown under a natural photoperiod in a greenhouse at Cracow Botanical Garden. Trees of similar height $(1.2-1.5 \mathrm{~m})$ and stem diameter $(2.0-2.5 \mathrm{~cm})$ at a height of $1 \mathrm{~m}$ were grown in $20-1$ containers. Soil composed of sand and compost (Universal Potting Soil, Pokon Naturado, Veenendaal, The Netherlands) was used in 1:1 proportion. Gas exchange measurements on leaves and bark were taken at a height of about 70-100 cm. After that, samples of leaves and bark were collected for biochemical analyses and epifluorescence microscopy. Samples for isotope analysis, chlorophyll content, acid concentration, and protein extraction were immediately immersed in liquid nitrogen and stored at $-80{ }^{\circ} \mathrm{C}$ until usage.

\section{Carbon isotope analysis in organic samples}

The frozen samples were oven dried for $24 \mathrm{~h}$ at $105^{\circ} \mathrm{C}$ before being ground to a fine powder for isotopic analysis. Isotope ratio measurements of $\mathrm{C}$ were performed on a Finnigan MAT 253 Mass Spectrometer coupled with a Flash HT Elemental Analyzer in continuous flow mode. Samples were weighed in tin capsules and introduced into the combustion furnace with a temperature of $1,020{ }^{\circ} \mathrm{C}$. A small volume of oxygen was added to the system to ensure the full combustion of organic compounds and conversion into elemental gases. $\mathrm{CO}_{2}$ was then separated in a chromatographic column (heated to $45^{\circ} \mathrm{C}$ ) and transferred in a carrier gas $(\mathrm{He})$ via a ConFlo IV Interface to the isotope ratio mass spectrometer. International isotope standards were used to calculate the results: USGS 40, USGS 41 and IAEA 600 (Coplen et al. 2006).

\section{Measurement of the $\mathrm{CO}_{2}$ concentration in stem tissues}

The $\mathrm{CO}_{2}$ concentration $\left(\left[\mathrm{CO}_{2}\right] ; \%\right)$ was measured at the height of $1 \mathrm{~m}$ from the base of the trees with a $\mathrm{CO}_{2} \mathrm{mi}$ croelectrode (model MI-414, Microelectrodes Inc., Bedford, NH) (McGuire and Teskey 2002). Four-mm-diameter holes were drilled $5 \mathrm{~mm}$ deep into the xylem. Teflon tubes (3.5 $\mathrm{mm}$ inner diameter and $30 \mathrm{~mm}$ length) were tightly fitted into the holes, and the tubes were sealed to the trees with flexible adhesive putty (Terostat IX, Henkel, Heidelberg, Germany).

The $\mathrm{CO}_{2}$ microelectrode was inserted in the tube, and adhesive putty was used to provide a gas-tight seal. The microelectrode measured the $\left[\mathrm{CO}_{2}\right]$ of the gas in the headspace of the hole, which was proportional to the concentration of all products of $\mathrm{CO}_{2}$ dissolved in the xylem sap. The $\left[\mathrm{CO}_{2}\right]$ of the gas $(\%)$ was converted to total dissolved carbon $\left(\left[\mathrm{CO}_{2}^{*}\right] \mathrm{mmol}^{-1}\right)$ by equations based on Henry's law (McGuire and Teskey 2002). For this conversion, the $\mathrm{pH}$ of the xylem sap must be known. Therefore, sap was expressed from an excised twig of the tree with a pressure chamber (PMS Instruments, Corvallis, OR) and measured with a $\mathrm{pH}$ electrode (model MI-720, Microelectrodes Inc., Bedford, $\mathrm{NH}$ ). The microelectrode was calibrated with two air samples of known $\left[\mathrm{CO}_{2}\right]$, and an exponential equation was developed to convert the millivolt output to $\left[\mathrm{CO}_{2}\right]$. The results were compensated for temperature by applying the equation empirically derived by McGuire and Teskey (2002).

\section{Gas exchange measurements}

The measurements of gas exchange were conducted in the leaves and stems under greenhouse conditions at 
$24{ }^{\circ} \mathrm{C}$ using a Portable Photosynthesis System LI-6400 (LI-COR Inc., Lincoln, NE, USA). The rates of $\mathrm{CO}_{2}$ and $\mathrm{H}_{2} \mathrm{O}$ efflux were measured using a standard chamber for leaves and a 6400-05 conifer chamber for stems. Measurements were performed under constant conditions: $24{ }^{\circ} \mathrm{C}, 25-30 \%$ relative humidity $(\mathrm{RH}), \mathrm{CO}_{2}$ concentration $385-400 \mu \mathrm{mol} \mathrm{mol}^{-1}$ and PPFD $400 \mu \mathrm{mol}$ photons $\mathrm{m}^{-2} \mathrm{~s}^{-1}$.

\section{Chlorophyll content}

Photosynthetic pigments chl $a$ and $b$ were measured in $80 \%$ acetone using the method described by Wellburn (1994).

\section{Protein extraction and quantification}

To determine the amount and diurnal changes of PEPC and Rubisco proteins in different plant parts of Clusia, the plant material, i.e., roots, stems, petioles and leaves, of $C$. rosea and C. multiflora was harvested at 7 a.m. and 2 p.m., then powdered in $\mathrm{N}_{2}$ and homogenized at $4{ }^{\circ} \mathrm{C}$ according to the method described by Taybi et al. (2004) with modification. Proteins $(35 \mu \mathrm{g})$ of each species were used for SDS PAGE electrophoresis in $12 \%$ polyacrylamide gels. Blotting was performed on a polyvinylidene fluoride membrane (PVPD) (Merck Millipore). Identification of PEPC and Rubisco (large subunit) bands was done with anti-PEPC polyclonal antibody (Agrisera), and detection was performed with alkaline phosphate buffer (AP) with BCIP/NBT as a substrate.

\section{Chlorophyll localization in stems}

The distribution of chlorophyll in stems was determined by using the autofluorescence of chla. Cross-section fragments of stems with a thickness of about $1 \mathrm{~mm}$ were soaked in a few drops of polyethylene glycol. The fluorescence images were recorded with a Bio-Rad MRC 1024 (Bio-Rad Microscience, Herts, UK) confocal microscope equipped with a Nikon Diaphot 300 microscope (Nikon, Amsterdam, The Netherlands) and a PlanFluor $10 \times$, NA 0.3 lens. The autofluorescence in the studied plant tissues was excited by a 488-nm line emitted by a 100-mW argon laser (ILT, USA). The images of square-shaped areas with $1,040-\mu \mathrm{m}$ sides were recorded using $512 \times 512$ pixels and 8-bit resolution. Fluorescence was recorded within a 515-630-nm range (cell walls) and 640-700-nm range (chl). In the combined confocal images, the fluorescence within the 515-630-nm range-representing the cell autofluorescence-had a green color and within the $640-700-\mathrm{nm}$ range-autofluorescence of chl-a red color.

\section{Malate and citrate determination}

Prior to cell sap collection, frozen bark and leaf samples were thawed for $3 \mathrm{~min}$. Then cell sap was obtained by extrusion with a squeezer and subsequently centrifuged for $4 \mathrm{~min}$ at $12,000 \times \mathrm{g}$. Malate and citrate were determined enzymatically according to Möllering, respectively (1974) and (1985).

\section{Statistics}

Statistical analyses of the data were made with Statistica 12.0 (Statsoft, Tulsa, OK, USA). The $\delta^{13} \mathrm{C}$ values, $\mathrm{CO}_{2}$ efflux and chlorophyll content were evaluated by statistical analysis of variance (ANOVA). Oscillations of the daily acid concentration in leaves and bark were analyzed by Student's $t$ test. Pictures from epifluorescence microscopy and electropherograms represent typical examples of five repetitions. Detailed information about statistic tests and the number of replicates is provided in the tables and figures.

\section{Results and discussion}

Cross sections of stems of C. multiflora and C. rosea (Fig. 1) reveal a similar anatomic structure of stems where a substantial part (about $25 \%$ ) consists of bark and is covered with a thin cork lacking stomata and lenticels. In the examined $8-9$-year-old stems, chlorophyll is concentrated mostly in the outer part of the bark. The presented pictures show that in these tissues the chlorophyll amount decreases in more deeply located cell layers and that the bark of C. multiflora is less rich in chlorophyll. The largest part of the stems in Clusia species is wood (approximately $65 \%$ ) and only about $10 \%$ the pith, both without visible amounts of chlorophyll. Pigment localization differs strongly from other typical $\mathrm{C}_{3}$ trees with thin cork (e.g., 6-year-old beech trunks) where chlorophyll is abundant in all living tissues including the pith and wood parenchyma (Pilarski and Tokarz 2006).

In the constitutive $\mathrm{C}_{3}$ plant $C$. multiflora, $\mathrm{PEPC}$ protein was detected in neither the leaves nor other plant organs. The level of Rubisco remained stable independently of the time point during the day (7 a.m., 2 p.m.) in leaves and other organs in both examined species. The abundance of the Rubisco protein was higher in $C$. rosea compared to $C$. multiflora. Immunoblot analysis indicated that in the constitutive CAM plant $C$. rosea, PEPC protein is present in all parts of the plant except the roots, and its abundance increases in the order: bark of the stem-petioles-leaves (Fig. 2). An effect of daytime on enzyme amount, however, was not observed. In $C$. rosea extracts, several bands 
Fig. 1 Cross-sections of 8-year-old stems of $C$. multiflora (a) and C. rosea (b), observed by epifluorescence microscopy. Red and green colors correspond to the autofluorescence of chlorophyll and cell walls respectively. $c p$ cortex parenchyma, $s c$ sclerenchyma, $p h$ phloem, $x y$ xylem. Scale bar $500 \mu \mathrm{m}$
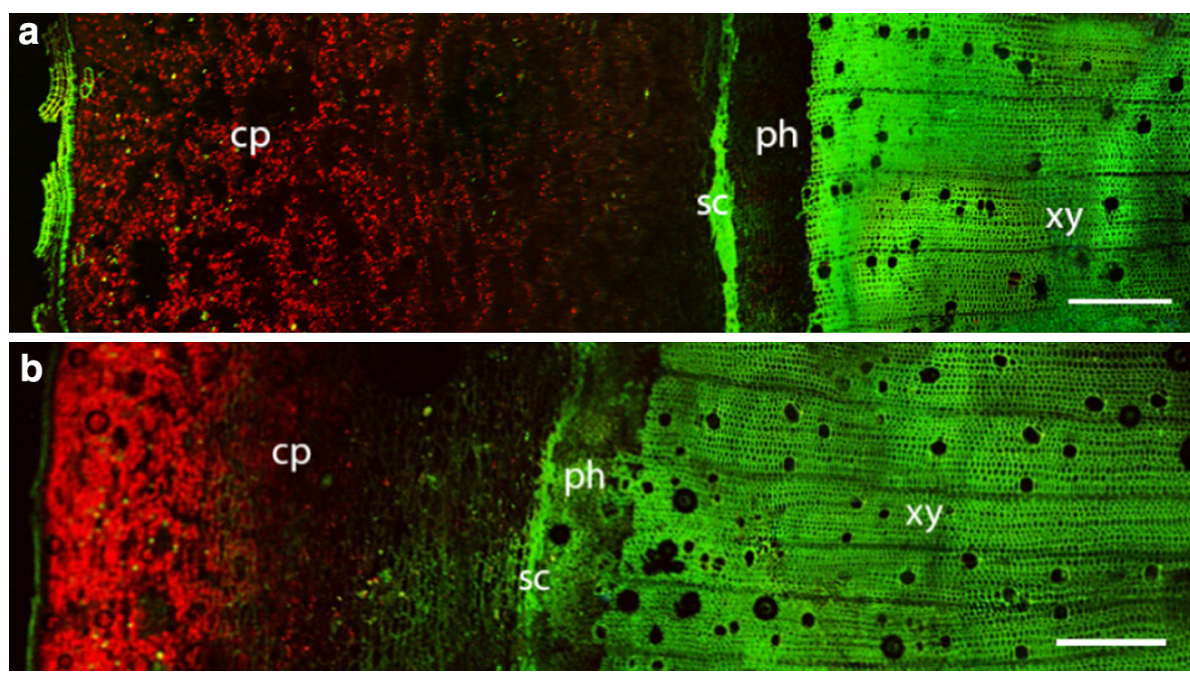

of PEPC protein were identified, most probably resulting from intensive day/night regulation of this enzyme. However, the other possible explanation could be the existence of functionally different PEPC isoforms as is the case in many CAM plants (Taybi et al. 2004).

In the experiments presented here, we were able to show significant amounts of $\mathrm{CO}_{2}$ within stems of both $\mathrm{C}_{3}$ and CAM Clusia species. In both plants kept under greenhouse conditions (day/night temperature $35 / 25^{\circ} \mathrm{C}$ ), fluctuations of the $\mathrm{CO}_{2}$ concentration showed a clear increase during the morning hours reaching the maximal value around midday, and much a lower concentration was observed during the night (Fig. 3). These fluctuations reflect changes in temperature well, and most probably they are due to respiratory and decarboxylating processes. Some cells in the bark of stems are equipped with chloroplasts, as shown in Fig. 1, and there is the possibility to use $\mathrm{CO}_{2}$ for photosynthesis. However, they are not able to fix all available carbon dioxide. To check the effectiveness of $\mathrm{CO}_{2}$ fixation in the analyzed plant organs excluding a temperature effect, we measured its concentration at a constant temperature of $24{ }^{\circ} \mathrm{C}$ during the day/night cycle. In measurements with both tested Clusia species, a clear increase during the night period and a decrease of the $\mathrm{CO}_{2}$ concentration during the daytime were found. When comparing the shapes of both curves (Fig. 3), it is observed that in $C$. multiflora these processes are less intensive during the first hours of light as well as during the first hours of dark periods in comparison with $C$. rosea. It is tempting to speculate that changes in $\mathrm{CO}_{2}$ fixation processes in $C$. rosea are more active in comparison to $C$. multiflora. However, we can not exclude that this is due to different respiratory characteristics in $C$. rosea.

$\mathrm{CO}_{2}$ gas exchange between stems and the atmosphere has been well described in the case of several trees and shrubs (Pfanz and Aschan 2001; Teskey et al. 2008; Bloemen et al. 2013), but nothing is known about these processes in the stems of Clusiacae. In our experiments we compared the $\mathrm{CO}_{2}$ exchange in leaves and stems of $C$. multiflora and $C$. rosea, and we found clear diel changes in the net photosynthesis characteristic for $\mathrm{C}_{3}$ and CAM plants, respectively (Fig. 4a). C. multiflora leaves start to fix $\mathrm{CO}_{2}$ with the onset of daytime, and a similar behavior was noted in fluctuations of $\mathrm{H}_{2} \mathrm{O}$ conductance (Fig. 4b). $C$. rosea leaves absorb large amounts of $\mathrm{CO}_{2}$ during the night, and this process decreases sharply with the onset of daytime. The total conductance to $\mathrm{H}_{2} \mathrm{O}$ shows a similar daily course. During the nighttime, leaves of $C$. rosea lose much more water than during the daytime; especially in the afternoon this process is very slow (Fig. 4a). In the stems of both plants these diel cycles did not occur (Fig. 4). Analyzing $\mathrm{CO}_{2}$ and $\mathrm{H}_{2} \mathrm{O}$ exchange (influx/efflux) in stems and leaves (at $24 / 24{ }^{\circ} \mathrm{C}$, day/night temperature) of C.multiflora and $C$. rosea (Table 1), we can state that stems are very tight structures, and only very small amounts of $\mathrm{CO}_{2}$ and $\mathrm{H}_{2} \mathrm{O}$ diffuse from them to the atmosphere.

Stems of succulent CAM plants with highly reduced or lacking leaves are able to effectively fix carbon during hot and dry periods. Their stems show net $\mathrm{CO}_{2}$-fixation rates of up to $10-20 \mu \mathrm{mol} \mathrm{CO}_{2} \mathrm{~m}^{-2} \mathrm{~s}^{-1}$ during the night (Nobel and Hartsock 1986). Also in many non-succulent $\mathrm{C}_{3^{-}}$perennials originating from semi-desert, desert and other seasonally dry habitats, green stems and twigs contribute an important proportion to the whole-plant carbon gain. In these plants the uptake of atmospheric $\mathrm{CO}_{2}$ reaches maximum rates of net stem photosynthesis of ca. 8-10 $\mu \mathrm{mol}$ $\mathrm{CO}_{2} \mathrm{~m}^{-2} \mathrm{~s}^{-1}$ during the day (Nilsen and Sharifi 1994). In woody stems and branches with strongly lignified tissues and bark layers, net photosynthesis was observed almost exclusively with halved twig segments or isolated 

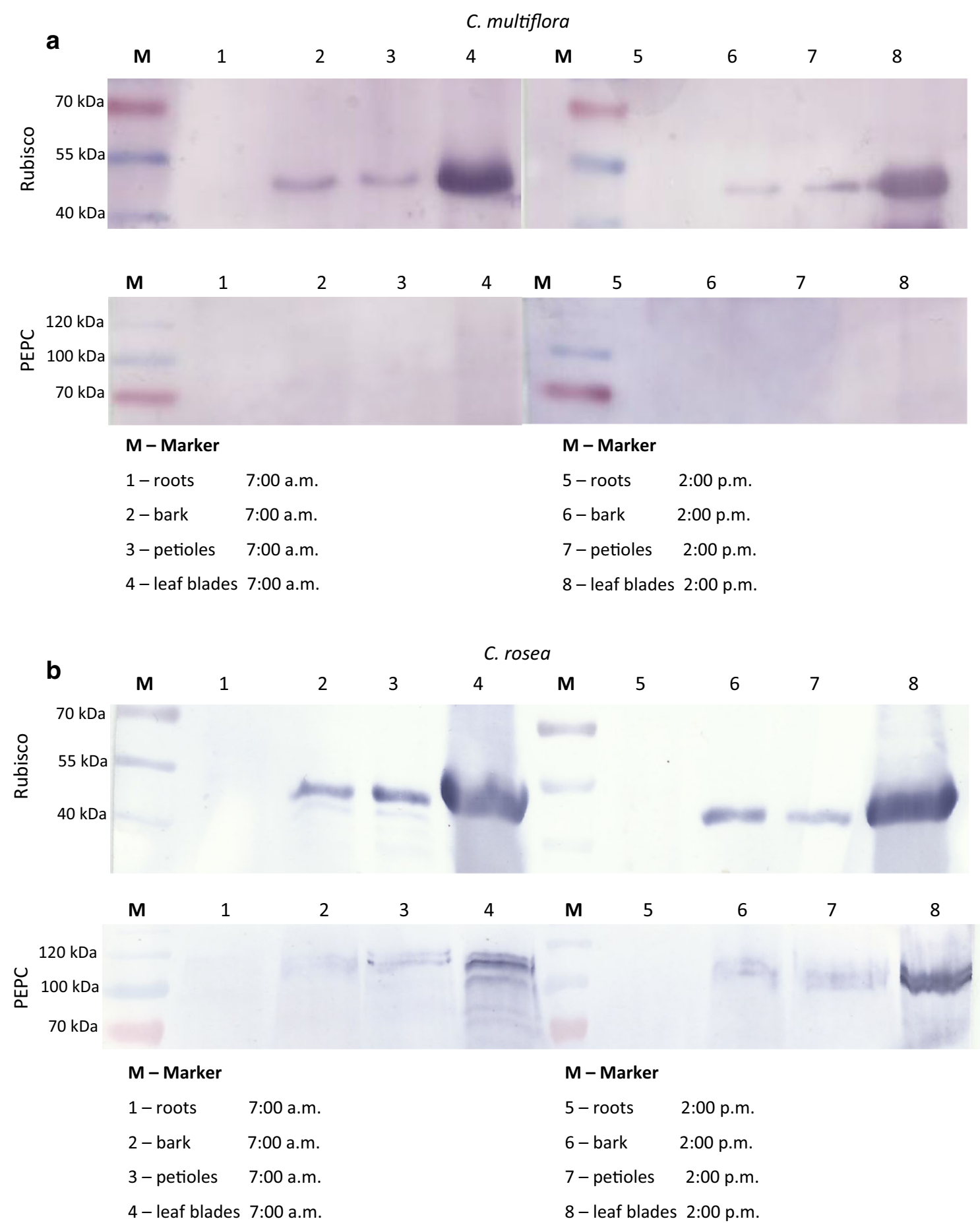

Fig. 2 Changes in Rubisco and PEPC abundance in roots, bark, petioles and leaf blades in C. multiflora (a) and C. rosea (b) at 7 a.m. (1-4) and 2 p.m. (5-8), respectively. An amount of marker $(M)(5 \mu \mathrm{g})$ and protein extract $(35 \mu \mathrm{g})$ was loaded to each lane

chlorenchymal tissues (Pfanz and Aschan 2001). In trees and schrubs, instead of net photosynthesis, respiratory $\mathrm{CO}_{2}$ efflux is widely observed in the range of $1-4 \mu \mathrm{mol} \mathrm{m}^{-2} \mathrm{~s}^{-1}$ (Saveyn et al. 2007; Cerasoli et al. 2009). Calculated from $\mathrm{CO}_{2}$ efflux (in light and dark conditions), efficient refixation of the respiratory $\mathrm{CO}_{2}$ is considered a photosynthetic phenomenon of plant stems (Pfanz and Aschan 2001; Cerasoli et al. 2009). Such refixation of internally available $\mathrm{CO}_{2}$ is also described for the chlorophyllous stems of herbaceous plants, such as, e.g., parasitic Cuscuta species (Hibberd et al. 1998). In the case of the tested two Clusia species, only low levels of $\mathrm{CO}_{2}$ efflux, 
Fig. 3 Daily temperature fluctuations (dotted lines) and $\mathrm{CO}_{2}$ concentration changes (solid lines) within stems of $C$. multiflora (a) and C. rosea (b). $T_{1}$ greenhouse conditions: temperature day/night $35 / 20{ }^{\circ} \mathrm{C}$, $20-35 \%$ relative humidity, $\mathrm{CO}_{2}$ concentration

410-480 $\mu \mathrm{mol} \mathrm{mol}^{-1}$, PPFD $=250-700 \mu \mathrm{mol}$ photons $\mathrm{m}^{-2} \mathrm{~s}^{-1} ; T_{2}$ growth chamber conditions: constant temperature $24{ }^{\circ} \mathrm{C}, 25-30 \%$ relative humidity, $\mathrm{CO}_{2}$ concentration

470-530 $\mu \mathrm{mol} \mathrm{mol}^{-1}$, $\mathrm{PPFD}=400 \mu \mathrm{mol}$

photons $\mathrm{m}^{-2} \mathrm{~s}^{-1}$. Each curve is for a representative stem of three replicate determinations
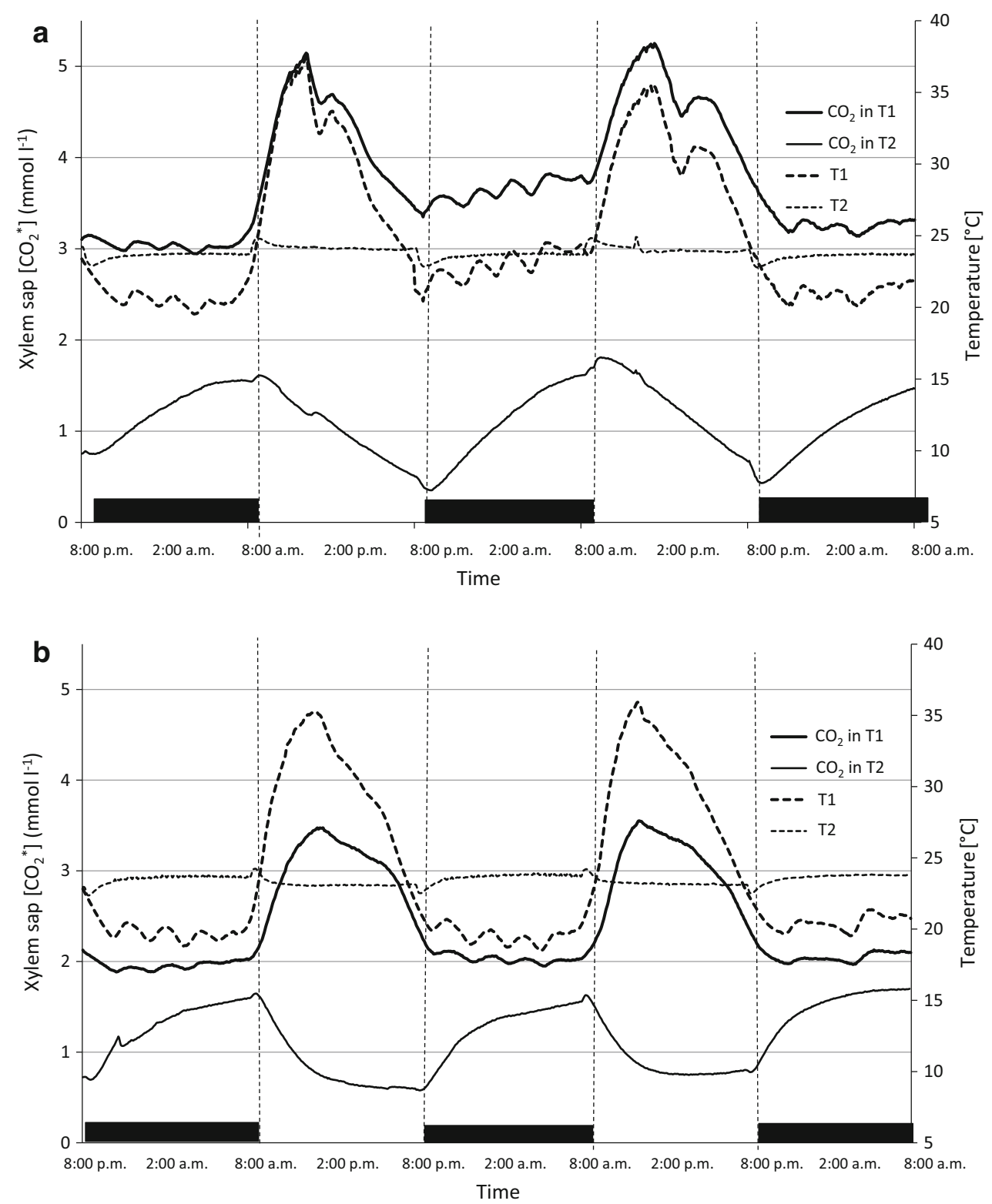

similar in the light and dark, were observed mostly in the range of $0.07-0.1 \mu \mathrm{mol} \mathrm{m} \mathrm{m}^{-2} \mathrm{~s}^{-1}$, and as a consequence, in our experiments, no measurable refixation was identified (Table 1). Our calculations of $\mathrm{CO}_{2}$ refixation in light in Clusia contrast with those reported for other species (Cernusak and Marshall 2000; Teskey et al. 2008; Cerasoli et al. 2009). The very low level of $\mathrm{CO}_{2}$ efflux in our plant material could be an effect of extremely low cork conductance $\left(0.15-0.2 \mathrm{mmol} \mathrm{m} \mathrm{m}^{-2}\right)$. Other trees showed higher conductance, e.g., ca. $1.0 \mathrm{mmol} \mathrm{m}^{-2} \mathrm{~s}^{-1}$ in 4-yearold stems of Pinus monticola (Cernusak and Marshall 2000) or $1.1 \mathrm{mmol} \mathrm{m}^{-2} \mathrm{~s}^{-1}$ in young stems of Betula pendula (Wittmann et al. 2006). Thus, in Clusia plants, the carbon dioxide present inside stems most probably comes from respiration or is transported from other plant organs.
"Saturation" of tissues with $\mathrm{CO}_{2}$ in Clusia stems decreases with the onset of day (Fig. 3). We may expect that limited decarboxylation of citrate and malate together with the high capacity of Rubisco-catalyzed carboxylation causes some of the $\mathrm{CO}_{2}$ to be used up during this part of the day. In stems of both plants, depletion of the $\mathrm{CO}_{2}$ concentration during the day (Fig. 3) cannot be the effect of PEPC activity, which is present in low but measurable amounts only in $C$. rosea. It is worth noting that malateinsensitive PEPC (very crucial for CAM metabolism) is mostly active during the night. Additionally, changes in the $\mathrm{CO}_{2}$ concentration during the light period are similar in both $\mathrm{C}_{3}$ and $\mathrm{CAM}$ plants. $\mathrm{CO}_{2}$ transport within some plants is strongly correlated with changes in the transpiration stream. According to Teskey and McGuire (2007), over a 

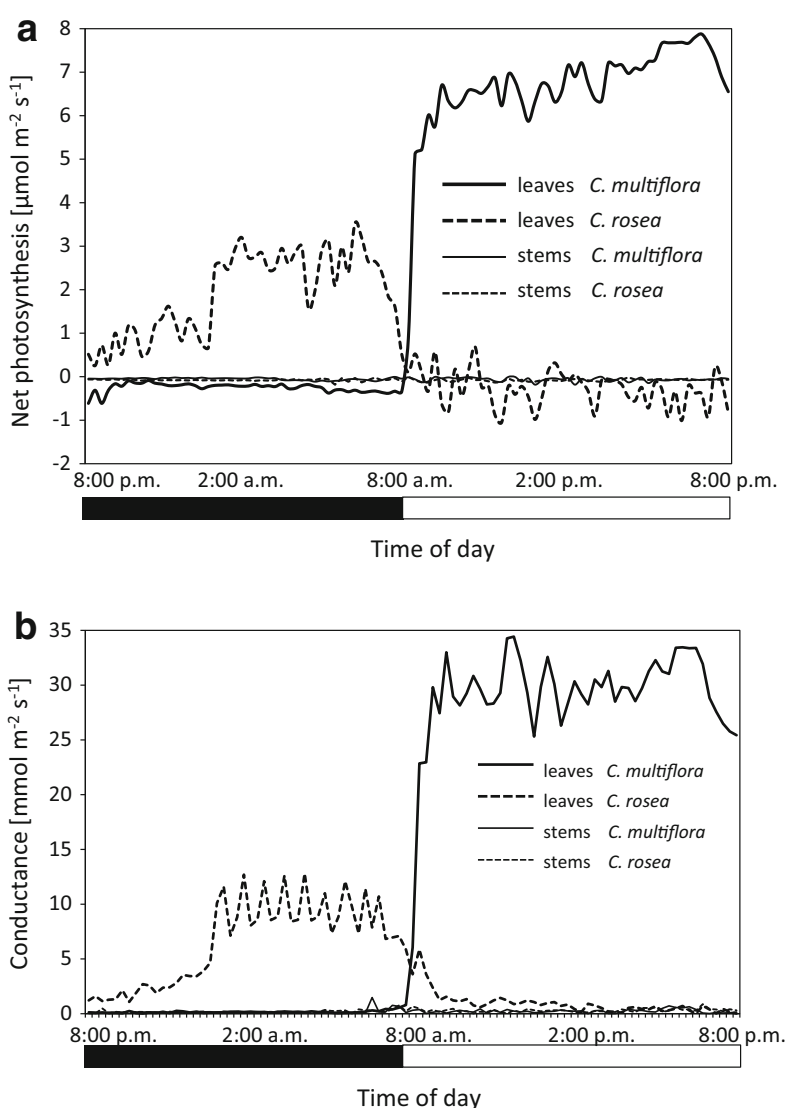

Fig. 4 Daily gas exchange fluctuations of leaves and stems of $C$. multiflora and $C$. rosea; a net photosynthetic rate $\left(P_{\mathrm{N}}\right)$; b total conductance to water vapor $\left(g_{\mathrm{tw}}\right)$. Measurements were performed under constant conditions: $24{ }^{\circ} \mathrm{C}, 25-30 \%$ relative humidity, $\mathrm{CO}_{2}$ concentration $\quad 385-400 \mu \mathrm{mol} \mathrm{mol}^{-1}, \quad$ PPFD $=400 \mu \mathrm{mol}$ photons $\mathrm{m}^{-2} \mathrm{~s}^{-1}$. Gas exchange curves are representative of three replicate runs with $\mathrm{SE}<5 \%,(n=3)$

Table $1 \mathrm{CO}_{2}$ release of stems of $C$. multiflora and $C$. rosea in the dark and light; after $30 \mathrm{~min}$ under illumination with $2000 \mu \mathrm{mol}$ photons $\mathrm{m}^{-2} \mathrm{~s}^{-1}$

\begin{tabular}{lll}
\hline Treatment & $\mathrm{CO}_{2}$ efflux $\left(\mu \mathrm{mol} \mathrm{CO}_{2} \mathrm{~m}^{-2} \mathrm{~s}^{-1}\right)$ \\
\cline { 2 - 3 } & C. multiflora & C. rosea \\
\hline Light & $0.073 \pm 0.008^{\mathrm{a}}$ & $0.100 \pm 0.009^{\mathrm{b}}$ \\
Dark & $0.070 \pm 0.007^{\mathrm{a}}$ & $0.103 \pm 0.009^{\mathrm{b}}$ \\
\hline
\end{tabular}

Measurements were performed under constant conditions $\left(20^{\circ} \mathrm{C}\right.$, $40-45 \%$ relative humidity) and at controlled $\mathrm{CO}_{2}$ supply $\left(400 \mu \mathrm{mol} \mathrm{mol}^{-1}\right)$. Data are mean $\pm \mathrm{SD}(n=10)$. Values marked with the same letters do not differ significantly according to Duncan's test; $P \leq 0.01$

whole day, $55 \%$ of the $\mathrm{CO}_{2}$ efflux to the atmosphere consists of $\mathrm{CO}_{2}$ that had been transported from lower parts of the tree. Moreover, stem girdling decreased the xylem $\mathrm{CO}_{2}$ concentration, indicating that belowground respiration contributes to the aboveground transport of internal $\mathrm{CO}_{2}$
Table $2{ }^{13} \mathrm{C}$ discrimination in leaves and bark of $C$. multiflora and $C$. rosea

\begin{tabular}{lll}
\hline Part of plant & \multicolumn{2}{l}{$\delta^{13} \mathrm{C}(\%)$} \\
\cline { 2 - 3 } & C. multiflora & C. rosea \\
\hline Leaves & $-30.58 \pm 0.36^{\mathrm{a}}$ & $-23.50 \pm 1.29^{\mathrm{b}}$ \\
Bark & $-30.81 \pm 0.08^{\mathrm{a}}$ & $-20.77 \pm 0.62^{\mathrm{c}}$ \\
\hline
\end{tabular}

Data are mean $\pm \operatorname{SD}(n=3)$. Values marked with the same letters do not differ significantly according to Duncan's test; $P \leq 0.05$

(Bloemen et al. 2014). Considering the conductance of leaves and the transpiration stream, which would move $\mathrm{CO}_{2}$ upward within the whole plant, this should occur in different time periods of the day: for $C$. rosea during the night and in C. multiflora during the day. Thus, we cannot expect that this is the main reason explaining the presence of $\mathrm{CO}_{2}$ in the stems of both Clusia plants. We expect that neither the transpiration stream nor PEPC activity, but rather photosynthetic activity, is responsible for the depletion of the $\mathrm{CO}_{2}$ concentration during the day in the stems of both plants.

There is a high difference in the $\delta^{13} \mathrm{C}$ discrimination value in $C$. rosea leaves (around $-23.5 \%$ ) compared to $C$. multiflora (around $-30.6 \%$ ) (Table 2). In stems this difference is even higher, ranging from almost -21 to $-31 \%$, respectively. Enrichment in ${ }^{13} \mathrm{C}$ in bulky organs in comparison to leaves is well known, but the mechanism of this phenomenon is not well understood (Badeck et al. 2005; Cernusak et al. 2009). According to Farquhar (1983), the main physiological factor responsible for shaping ${ }^{13} \mathrm{C}$ is the discrimination of the ${ }^{13} \mathrm{C}$ isotope by Rubisco and to a much lesser extent by PEPC. In fact, PEPC activity in stems of $\mathrm{C}_{3}$ plants (in 1-year Fagus sylvatica and the herbaceous plant Reynoutria japonica) can be even higher than in leaves (Berveiller et al. 2007; Kocurek and Pilarski 2011). The results presented here on $C$. multiflora and $C$. rosea do not support these observations, and we show some amount of PEPC in $C$. rosea and no measurable amounts in C. multiflora (Fig. 2). In C. rosea this protein is much better expressed in leaves than in stems, which is characteristic for CAM plants. If so, most carbon fixed in the $C$. multiflora body is due to Rubisco activity, without prefixation (with PEPC).

In C. multiflora the $\delta^{13} \mathrm{C}$ value reaches less than $-30 \%$ and is similar in leaves and bark. It seems interesting that when comparing the $\delta^{13} \mathrm{C}$ for $C$. rosea, bark tissue shows less discrimination than leaves (Table 2). Similar results concerning strong and weak CAM Clusia were obtained by Cernusak et al. (2008). Thus, a substantial part of carbon incorporated in stems possibly was fixed in a pre-fixation process. Continuing this line of interpretation, we can expect that the origin of carbon within stems of $C$. rosea is 
more due to PEPC activity than in leaves. We can speculate that if this carbon originated from the $\mathrm{CO}_{2}$ produced in respiratory processes, this would show similar discrimination as in other plant tissues. Thus, the less negative $\delta^{13} \mathrm{C}$ value in the bark tissue in $C$. rosea (and the difference between leaves and bark) would mean that at least some part of $\mathrm{CO}_{2}$ in the bark is fixed because of PEPC activity. It can be expected that $\mathrm{CO}_{2}$ is fixed in roots and transported via vascular tissues to stems, as shown by Hibberd and Quick (2002), and in this way participates in building carbon skeletons of the cell walls in the bark. However, this transpiration stream does not seem very intensive in the case of Clusia species (Herrera et al. 2008). If we assume that the final ${ }^{13} \mathrm{C}$ discrimination level depends mostly on Rubisco and PEPC activities, we may also expect that more carbon incorporated in bark tissue comes from pre-fixation in comparison to leaves. We may suspect that bark tissue is growing more intensively during time periods when the $\mathrm{PEPC} /$ Rubisco activity ratio is increased. Moreover, in $C$. rosea the low value of $\delta^{13} \mathrm{C}$ in stems (which is lower than in leaves) would indicate that photosynthetizing cells in bark tissue intensively use carbon dioxide pre-fixed in the reaction catalyzed by PEPC, and this may also be transported from the other tissues. In addition to this, we know that tissues rich in chloroplasts (lipid-rich organelles) show higher discrimination (more negative $\delta^{13} \mathrm{C}$ values). We have not observed such differences in $C$. multiflora (Table 2), but in C. rosea this difference was higher than observed for Mimosa naguirei (Fernandes et al. 1998). Thus, in our experiments about a $3 \%$ difference between the bark and leaves in C. rosea is probably the effect of both: the depletion in chloroplasts and PEPC activity as shown in Fig. 2b.

The chlorophyll amount calculated on the area of the plant organ in leaves of $C$. multiflora is higher than in bark (Fig. 5). Opposite to this in C. rosea, the total amount of both chlorophylls is lower in leaves in comparison to bark. A high amount of chlorophyll in bark (comparable to $C$. multiflora leaves) could be an additional factor enabling efficient photosynthesis in this plant organ. The chlal chl $b$ ratio is somehow lower or significantly lower in bark in comparison to their leaves in both tested Clusia species, and probably most of these differences are because of lower light intensity and different wavelengths of light reaching photosynthesizing cells localized in the bark. A lower chla/ chl $b$ ratio indicates that the PSI/PSII activity ratio is lower (Walters 2005). Thus, we can expect that in the bark oxygen production in the water splitting system within PSII is important. The relationship between the $\mathrm{CO}_{2}$ and $\mathrm{O}_{2}$ concentration in photosynthesizing organs was studied also in detail in the case of fruits, organs with a limited possibility to exchange $\mathrm{CO}_{2}$ and $\mathrm{O}_{2}$ with the atmosphere (Borisjuk and Rollentschek 2009). In these bulky organs, covered with a
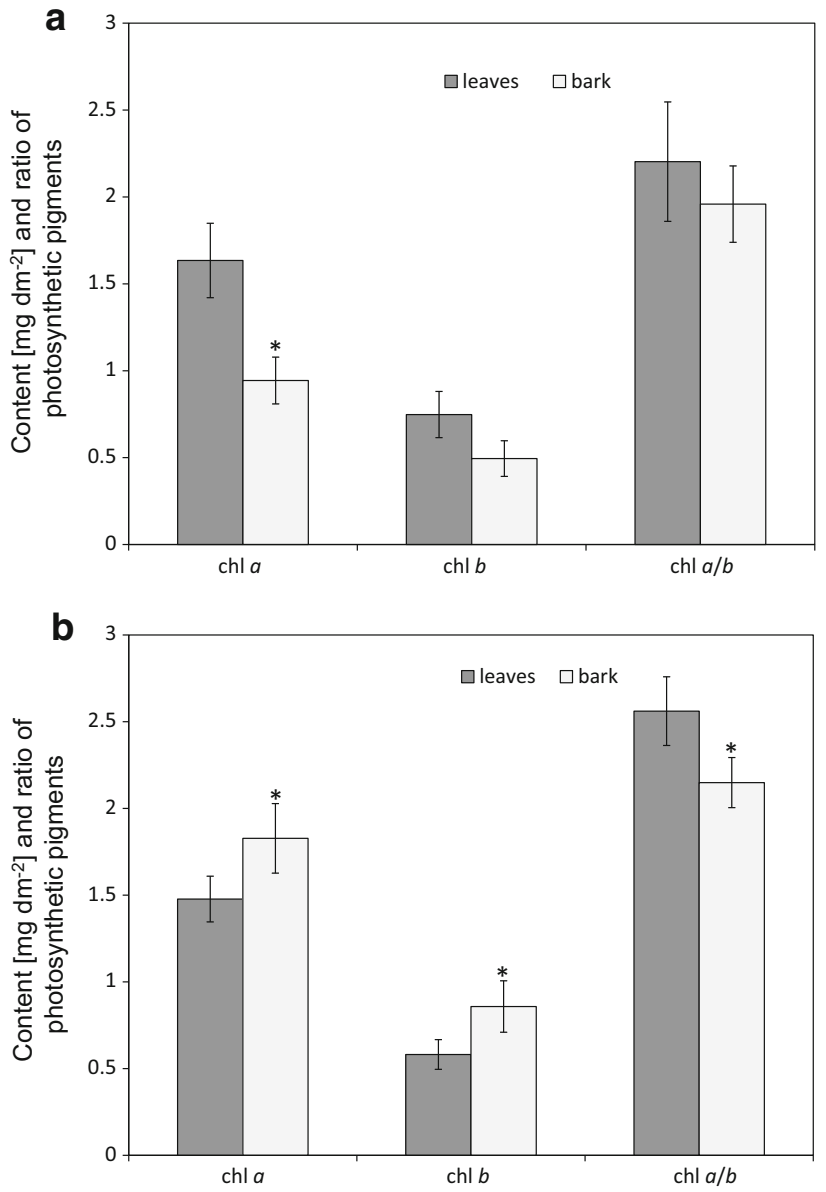

Fig. 5 Chlorophyll content and chlorophyll $a / b$ ratios of leaves and bark of $C$. multiflora (a) and C. rosea (b). Data are mean $\pm \mathrm{SD}$ $(n=5)$. Asterisks indicate significant differences between leaves and stems according to Duncan's test; $P \leq 0.05$

low-permeable epidermis, photosynthesizing cells deliver $\mathrm{O}_{2}$ for deeper heterotrophic layers including seeds (Lytovchenko et al. 2011). As mentioned for Mesembryanthemum crystallinum leaves in the CAM state (Miszalski et al. 2001), an excess of $\mathrm{O}_{2}$ in Clusia probably cannot diffuse out of stems and can be removed during respiration in mitochondria or photorespiration in chloroplasts. This can help in $\mathrm{CO}_{2}$ production and its fixation by Rubisco in chloroplasts. Sap flux is considered the major source of $\mathrm{O}_{2}$ in the xylem (Gansert 2003), but the importance of $\mathrm{O}_{2}$ generated by stem photosynthesis may increase when sap flux is diminished. Gansert (2003) reported that when sap flow was reduced, the $\mathrm{O}_{2}$ deficit in Betula pubescens stems increased dramatically; under these conditions, any $\mathrm{O}_{2}$ provided by stem photosynthesis would help in maintaining adequate rates of respiration.

When comparing day/night fluctuations of malate and citrate, the two most important acids responsible for the accumulation of $\mathrm{CO}_{2}$ in CAM plants, we have shown that there are differences between both tested Clusia species 


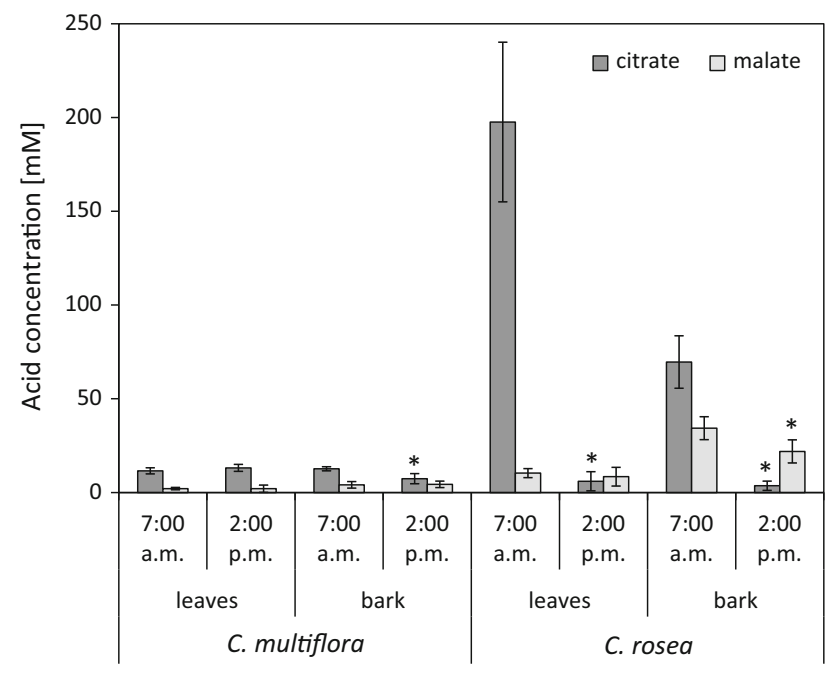

Fig. 6 Malate and citrate concentrations in cell sap in the leaves and bark of $C$. multiflora and $C$. rosea collected at 7 a.m. and 2 p.m.; data are mean $\pm \mathrm{SD}(n=5)$. $T$ tests were performed for values of corresponding pairs ( 7 a.m. and 2 p.m.) for leaves and stems separately. Asterisks indicate significant differences compared to 7 a.m. at $P \leq 0.05$

(Fig. 6). As expected, in leaves of $\mathrm{C}_{3}$ C. multiflora, no day/ night differences were identified in either the level of citrate or malate. In bark tissue only very small differences were observed in the citrate level, indicating that some small amounts of citrate $(5 \mathrm{mM})$ are accumulated during the night hours and are decarboxylated during the morning hours. In leaves of CAM C. rosea no significant malate fluctuations were observed, and the very high differences in citrate levels show that mostly citrate acid participates in active CAM-type metabolism. Very clear nocturnal accumulation in citrate levels was also noted in bark tissue. Accumulation of citrate during night hours was not as high as in leaves, and its decarboxylation was very efficient. Thus, the citrate level during the afternoon hours was very low.

If we assume that photosynthetizing cells in bark tissue obtain much less light energy than leaf cells, we can compare these measurements with those we presented in experiments made on another CAM plant. C. hilariana (Miszalski et al. 2013). Also in these experiments leaves kept at low light accumulated much less malate than leaves growing in high light, and the citrate level even increased during the day. Our experiments on C. hilariana allowed us to speculate that in plants growing at high light, the TCA cycle is less active during the daytime because photosynthesis delivers most of the necessary energy and helps to use citrate. As suggested by the results in Fig. 3, the function of mitochondria during the day has to be reduced because of limited access to oxygen from the air. Mitochondria can use only the oxygen that is produced in photosynthesis. However, this citrate level and mitochondrial activity are reduced, and the $\mathrm{CO}_{2}$ produced in the decarboxylation process is fixed in photosynthesis. However, the $\mathrm{O}_{2}$ concentration in phase III of CAM behind closed stomata can be very high so that even photorespiration occurs (Lüttge 2011). It can be also suggested that an important role of chloroplasts in the stems of Clusia is to deliver oxygen for respiration during the daytime. This explanation would be also helpful to understand why many Clusia plants occupy very dry niches and may grow with relatively low photosynthetic gas exchange, and they often show parallel malate and citrate fluctuations during the day/night cycle. This can also explain the high plasticity of the Clusiaceae family to changing environments (Lüttge 2006).

\section{Conclusions}

1. Stems of both Clusia species representing $\mathrm{C}_{3}$ and CAM are closed structures, characterized by low gas exchange with the atmosphere.

2. Available $\mathrm{CO}_{2}$ within stems is limited, and possibly also efflux of $\mathrm{O}_{2}$ produced because of photochemical activity of PSII is slow. Thus, internally produced $\mathrm{O}_{2}$ can be used for photorespiration and dark respiration. This seems to be more important for trees from arid environments like Clusia in comparison to trees in temperate forests.

3. Not only in leaves but also in stems, the obligatory CAM plant $C$. rosea performs $\beta$-carboxylation.

Author contribution statement $\mathrm{ZM}, \mathrm{AK}$, and JP conceived and designed experiments; MK and ZM wrote the manuscript; AK and UL prepared the figures and redaction of the manuscript; MK performed most experimental analyses; KT performed Western blot analysis; $\mathrm{ZM}, \mathrm{AK}$, and UL carried out data analysis and JP pigment analysis.

Acknowledgments This work was supported by the Polish National Science Center (research grant nos. N N304 156440 and 2011/01/B/ NZ9/02540).

Conflict of interest The authors declare that they have no conflict of interest.

Open Access This article is distributed under the terms of the Creative Commons Attribution License which permits any use, distribution, and reproduction in any medium, provided the original author(s) and the source are credited.

\section{References}

Badeck FW, Tcherkez G, Nogues S, Piel C, Ghashghaie J (2005) Postphotosynthetic fractionation of stable carbon isotopes between plant organs-a widespread phenomenon. Rapid Commun Mass Spectrom 19:1381-1391 
Berveiller D, Damesin C (2008) Carbon assimilation by tree stems: potential involvement of phosphoenolpyruvate carboxylase. Trees Struct Funct 22:149-157

Berveiller D, Kierzkowski D, Damesin C (2007) Interspecific variability of stem photosynthesis among tree species. Tree Physiol 27:53-61

Bloemen J, McGuire MA, Aubrey DP, Teskey RO, Steppe K (2013) Transport of root-respired $\mathrm{CO}_{2}$ via the transpiration stream affects aboveground carbon assimilation and $\mathrm{CO}_{2}$ efflux in trees. New Phytol 197:555-565

Bloemen J, Agneessens L, Meulebroek L, Aubrey DP, McGuire MA (2014) Stem girdling affects the quantity of $\mathrm{CO}_{2}$ transported in xylem as well as $\mathrm{CO}_{2}$ efflux from soil. New Phytol 201:897-907

Borisjuk L, Rollentschek H (2009) The oxygen status of the developing seed. New Phytol 182:17-30

Cerasoli S, McGuire MA, Faria J, Mourato M, Schmidt M, Pereira JS, Chaves MM, Teskey RO (2009) $\mathrm{CO}_{2}$ efflux, $\mathrm{CO}_{2}$ concentration and photosynthetic refixation in stems of Eucalyptus globulus (Labill.). J Exp Bot 60:99-105

Cernusak LA, Marshall JD (2000) Photosynthetic refixation in branches of Western White Pine. Funct Ecol 14:300-311

Cernusak LA, Mejia-Chang M, Winter K, Griffiths H (2008) Oxygen isotope composition of CAM and $\mathrm{C}_{3}$ Clusia species: non-steadystate dynamics control leaf water ${ }^{18} \mathrm{O}$ enrichment in succulent leaves. Plant Cell Environ 31:1644-1662

Cernusak LA, Tcherkez G, Keitel C, Cornwell WK, Santiago LS, Knohl A, Barbour MM, Williams DG, Reich PB, Ellsworth DS, Dawson TE, Griffiths HG, Farquhar GD, Wright IJ (2009) Why are non-photosynthetic tissues generally ${ }^{13} \mathrm{C}$ enriched compared with leaves in $\mathrm{C}_{3}$ plants? Review and synthesis of current hypotheses. Funct Plant Biol 36:199-213

Cernusak LA, Ubierna N, Winter K, Holtum JA, Marshall JD, Farquhar GD (2013) Environmental and physiological determinants of carbon isotope discrimination in terrestrial plants. New Phytol 200:950-965

Coplen TB, Brand WA, Gehre M, Gröning M, Meijer HAJ, Toman B, Verkouteren RM (2006) New Guidelines for ${ }^{13} \mathrm{C}$ Measurements. Anal Chem 78:2439-2441

Craig H (1953) The geochemistry of the stable carbon isotopes. Geochim Cosmochim Ac 3:53-92

Damesin C, Lelarge C (2003) Carbon isotope composition of currentyear shoots from Fagus sylvatica in relation to growth, respiration and use of reserves. Plant Cell Environ 26:207-219

DeNiro MJ, Epstein S (1977) Mechanism of carbon isotope fractionation associated with lipid synthesis. Science 197:261-263

Etzold S, Zweifel R, Ruehr NK, Eugster W, Buchmann N (2013) Long-term stem $\mathrm{CO}_{2}$ concentration measurements in Norway spruce in relation to biotic and abiotic factors. New Phytol 197:1173-1184

Farquhar GD (1983) On the nature of carbon isotope discrimination in $\mathrm{C}_{4}$ species. Aust J Plant Physiol 10:205-226

Fernandes GW, de Mattos EA, Franco AC, Lüttge U, Ziegler H (1998) Influence of the parasite Pilostyles ingae (Rafflesiaceae) on some physiological parameters of the host plant, Mimosa naguirei (Mimosaceae). Bot Acta 111:51-54

Gansert D (2003) Xylem sap flow as a major pathway for oxygen supply to the sapwood of birch (Betula pubescens Ehr.). Plant Cell Environ 26:1803-1814

Herrera A, Ballestrini C, Tezara W (2008) Nocturnal sap flow in the $\mathrm{C}_{3}$-CAM species, Clusia minor. Trees Struct Funct 22:491-497

Hibberd JM, Quick WP (2002) Characteristics of $\mathrm{C}_{4}$ photosynthesis in stems and petioles of $\mathrm{C}_{3}$ flowering plants. Nature 415:451-454

Hibberd JM, Bungard RA, Press MC, Jeschke WD, Scholes JD, Quick WP (1998) Localization of photosynthetic metabolism in the parasitic angiosperm Cuscuta reflexa. Planta 205:506-513
Janacek SH, Trenkamp S, Palmer B, Brown NJ, Parsley K, Stanley S, Astley HM, Rolfe SA, Quick WP, Fernie AR, Hibberd JM (2009) Photosynthesis in cells around veins of the C-3 plant Arabidopsis thaliana is important for both the shikimate pathway and leaf senescence as well as contributing to plant fitness. Plant J 59:329-343

Kocurek M, Pilarski J (2011) Activity of $\mathrm{C}_{4}$ enzymes in $\mathrm{C}_{3}$-type herbaceous plants. Photosynthetica 49:473-477

Kornas A, Fischer-Schliebs E, Lüttge U, Miszalski Z (2009) Adaptation of the obligate CAM plant Clusia alata to light stress: metabolic responses. J Plant Physiol 166:1914-1922

Lüttge U (2004) Ecophysiology of Crassulacean acid metabolism (CAM). Ann Bot Lond 93:629-652

Lüttge U (2006) Photosynthetic flexibility and ecophysiological plasticity: questions and lessons from Clusia, the only CAM tree, in the neotropics. New Phytol 171:7-25

Lüttge U (2008) Clusia: Holy Grail and enigma. J Exp Bot 59:1503-1514

Lüttge U (2011) Photorespiration in phase III of crassulacean acid metabolism: evolutionary and ecophysiological implications. Prog Bot 72:371-384

Lytovchenko A, Eickmeier I, Pons C, Osorio S, Szecowka M, Lehmberg K, Arrivault S, Tohge T, Pineda B, Anton MT, Hedtke B, Lu Y, Fisahn J, Bock R, Stitt M, Grimm B, Granell A, Fernie AR (2011) Tomato fruit photosynthesis is seemingly unimportant in primary metabolism and ripening but plays a considerable role in seed development. Plant Physiol 157:1650-1663

McGuire MA, Teskey RO (2002) Microelectrode technique for in situ measurements of carbon dioxide concentrations in xylem sap of trees. Tree Physiol 22:807-811

Miszalski Z, Niewiadomska E, Ślesak I, Lüttge U, Kluge M, Ratajczak R (2001) The effect of irradiation on carboxylating/ decarboxylating enzymes and fumarase activities in Mesembryanthemum crystallinum L. exposed to salinity stress. Plant Biol 3:17-23

Miszalski Z, Kornas A, Rozpadek P, Fischer-Schliebs E, Lüttge U (2013) Independent fluctuations of malate and citrate in the CAM species Clusia hilariana Schltdl. under low light and high light in relation to photoprotection. J Plant Physiol 170:453-458

Möllering H (1974) Malat. Bestimmung mit Malat-Dehydrogenase und Glutamat-Oxalacetat-Transaminase. In: Bergmeyer HU (ed) Methoden der Enzymology. Academic Press, New York, pp 1636-1639

Möllering H (1985) Citrate. determination with citrate lyase, MDH and LDH. In: Bergmeyer HU (ed) Methods of enzymatic analysis. Academic Press, New York, pp 2-12

Nier AO, Gulbransen EA (1939) Variations in the relative abundance of the carbon isotopes. J Am Chem Soc 61:697-698

Nilsen ET, Sharifi M (1994) Seasonal acclimation of stem photosynthesis in woody legume species from the Mojave and Sonoran deserts of California. Plant Physiol 105:1385-1391

Nobel PS, Hartsock L (1986) Leaf and stem $\mathrm{CO}_{2}$ uptake in the three subfamilies of the Cactaceae. Plant Physiol 80:913-917

Pfanz H, Aschan G (2001) The existence of bark and stem photosynthesis in woody plants and its significance for the overall carbon gain. An eco-physiological and ecological approach. Prog Bot 62:477-510

Pilarski J, Tokarz K (2006) Chlorophyll distribution in the stems and trunk of beech trees. Acta Physiol Plant 28:233-236

Saveyn A, Steppe K, Lemeur R (2007) Drought and the diurnal patterns of stem $\mathrm{CO}_{2}$ efflux and xylem $\mathrm{CO}_{2}$ concentration in young oak (Quercus robur). Tree Physiol 27:365-375

Taybi T, Nimmo HG, Borland AM (2004) Expression of phosphoenolpyruvate carboxylase and phosphoenolpyruvate carboxylase kinase genes. Implications for genotypic capacity and 
phenotypic plasticity in the expression of Crassulacean acid metabolism. Plant Physiol 135:587-598

Teskey RO, McGuire MA (2007) Measurement of stem respiration of sycamore (Platanus occidentalis L.) trees involves internal and external fluxes of $\mathrm{CO}_{2}$ and possible transport of $\mathrm{CO}_{2}$ from roots. Plant Cell Environ 30:570-579

Teskey RO, Saveyn A, Steppe K, McGuire MA (2008) Origin, fate and significance of $\mathrm{CO}_{2}$ in tree stems. New Phytol 177:17-32

Walters RG (2005) Towards an understanding of photosynthetic acclimation. J Exp Bot 411:435-447
Wellburn AR (1994) The spectral determination of chlorophylls a and $\mathrm{b}$ as well as total carotenoids, using various solvents with spectrophotometers of different resolution. J Plant Physiol 144:307-313

Wittmann C, Pfanz H, Loreto F, Centritto M, Pietrini F, Alessio G (2006) Stem $\mathrm{CO}_{2}$ release under illumination: corticular photosynthesis, photorespiration or inhibition of mitochondrial respiration? Plant Cell Environ 29:1149-1158 